Chirurgia (2020) 115: 618-625

No. 5, September - October

Copyright@ Celsius

\title{
Effectiveness of Doppler Ultrasonography as a Predictor of Wound Healing after Below-Knee Amputation for Peripheral Arterial Disease
}

\author{
Fachrul Junaidi', Akhmadu Muradi' ${ }^{*}$, Dedy Pratama', Raden Suhartono', Aria Kekalih² \\ 'Division of Vascular and Endovascular Surgery, Department of Surgery, Dr. Cipto Mangunkusumo General Hospital, \\ Faculty of Medicine Universitas Indonesia, Jakarta, Indonesia \\ ${ }^{2}$ Department of Community Medicine, Faculty of Medicine, Universitas Indonesia, Jakarta, Indonesia
}

*Corresponding author: Akhmadu Muradi, MD, PhD

Division of Vascular and Endovascular Surgery, Department of Surgery Dr. Cipto Mangunkusumo General Hospital, Faculty of Medicine Universitas Indonesia, Jakarta, Indonesia E-mail: akhmadumuradi@gmail.com

\section{Abbreviations:}

BKA - Below-Knee Amputation, PAD - Peripheral Artery Disease, CLI - Critical Limb Ischemia,

TTT - Triphasic Triphasic Triphasic, TTB - Triphasic Triphasic Biphasic, TBT - Triphasic Biphasic Triphasic, TTM - Triphasic Triphasic Monophasic, TMT - Triphasic Monophasic Triphasic, TBB - Triphasic Biphasic Biphasic, TBM - Triphasic Biphasic Monophasic, TMB - Triphasic Monophasic Biphasic, NNN - Normal Normal Normal, NNA - Normal Normal Abnormal, NAN - Normal Abnormal Normal, NAA - Normal Abnormal Abnormal, ALI - Acute Limb Ischemia.

Received: 16.06 .2020 Accepted: 12.08 .2020

\section{Rezumat}

Eficacitatea ultrasonografiei Doppler ca predictor de vindecare a rănilor după amputarea sub genunchi pentru boala arterială periferică

Context: Este necesar un instrument pentru a prezice modul în care rana rezultată după amputația sub genunchi se va vindeca la pacientul cu boală arterială periferică. Ultrasonografia este o alternativă pentru evaluarea stării arterelor. Am efectuat un studiu pentru a investiga asocierea între ultrasonografia Doppler ca evaluare pre-amputare, cu vindecarea primară a rănilor după amputarea sub genunchi.

Metode: Un studiu de caz-martor a fost efectuat pentru a investiga eficacitatea ultrasonografiei ca predictor al vindecării rănilor. Au fost efectuate analize bivariate şi multivariate pentru a explora asocierea între indicatorii ultrasonografici, inclusiv viteza sistolică maximă, fluxul volumetric, diametrul arterial şi forma de undă spectrală a arterei distale, cu vindecarea plăgii după amputație. Evaluările ultrasonografice au fost efectuate pe artera poplitee, artera tibială anterioară şi artera tibială posterioară.

Rezultate: Pe baza analizei multivariate pe toate arterele, au existat asociatii semnificative statistic ale vitezei sistolice maxime (risc relativ $[\mathrm{OR}]=5,584$, interval de încredere 95\% [CI] = 1,291 $24,157, \mathrm{p}=0,021$ ), flux volumetric $\mathrm{OR}$ ajustat $=4,760,95 \% \mathrm{CI}=1,200$ - $18,876, p=0,026$ ) şi diametrul arterial (ajustat $\mathrm{OR}=6,507,95 \% \mathrm{CI}$ $=1,510-28,033, \mathrm{p}=0,012)$ cu vindecarea rănilor după amputație.

Concluzie:Ecografia Doppler în cazul bolii arteriale periferice poate fi utilizată ca modalitate predictivă de testare pre-amputare pentru a prezice vindecarea rănilor după amputarea sub genunchi. 
Cuvinte cheie: ultrasonografie, boală arterială periferică, amputare sub genunchi, evaluare preamputare

\begin{abstract}
Background: A tool is needed to predict how wound following below-knee amputation (BKA) surgery will heal in patient with peripheral artery disease (PAD). Ultrasonography is an alternative to evaluate the condition of the arteries. We conducted a study to investigate the association between doppler ultrasonography as pre-amputation assessment with primary wound healing following BKA surgery.

Methods: A case-control study was conducted to investigate the effectiveness of ultrasonography as a predictor of the wound healing. Bivariate and multivariate analysis were performed to explore association between ultrasonography indicators including peak systolic velocity, volume flow, arterial diameter, and distal artery spectral waveform with wound healing following BKA. Ultrasonography assessments were conducted on the popliteal artery, anterior tibial artery, and posterior tibial artery.

Results: Based on the multivariate analysis on all arteries, there were statistically significant associations of peak systolic velocity (adjusted odd ratio $[\mathrm{OR}]=5.584,95 \%$ confidence interval $[\mathrm{CI}]=1.291-24.157, \mathrm{p}=0.021$ ), volume flow (adjusted $\mathrm{OR}=4.760,95 \% \mathrm{CI}=1.200-18.876$, $\mathrm{p}=0.026$ ), and arterial diameter (adjusted $\mathrm{OR}=6.507,95 \% \mathrm{CI}=1.510-28.033, \mathrm{p}=0.012$ ) with wound healing after BKA.

Conclusion: Doppler ultrasonography of $\mathrm{PAD}$ can be used as a predictive pre-amputation testing modality to predict wound healing after BKA.
\end{abstract}

Key words: ultrasonography, peripheral arterial disease, below-knee amputation, pre-amputation assessment

\section{Introduction}

Critical limb ischemia (CLI) in peripheral arterial disease $(\mathrm{PAD})$ is associated with high risks of morbidity and mortality $(1,2)$. The prevalence of $\mathrm{PAD}$ ranges from $1.6-12 \%(3,4)$. in the general population, $1-2 \%$ of which are estimated to be critical limb ischemia (5). Nehler, et al. reported in 2014 that the prevalence of critical limb ischemia had increased to $11.08 \%$ of patients with PAD (4). Amputation is often regarded as the last resort for treatment of uncontrollable pain or infection in patients with PAD. Patients with chronic ischemic limb conditions have a limb loss rate in 3 years of around $40 \%$ (2). Moreover, up to $28 \%$ of diabetic foot patients with PAD had to undergo amputations (both minor and major) in the last 3 years (6). Preservation of a major joint may result in a higher probability of lower energy expenditure and ambulation continuity for the patients (7). Hence, belowknee amputation (BKA) would be more preferable. About $60 \%$ of BKA surgery results heal by primary intention, and 15\% heal after undergoing a secondary procedure (8). However, $15 \%$ of cases must be converted to above-knee amputations. Many factors can influence the possibility of amputation failure, including the ischemic condition, infection, hematoma, and trauma. Previously, considerations of the level of amputation was largely dependent on clinical vascular measurements, including simple clinical assessments such as capillary refill assessment or the pulses of the posterior tibial and dorsal pedal arteries evaluations (9). However, previous studies reported the difficulty of relying only on 
patient history and physical examinations as pre-amputation evaluations (10). Hence, another modality is needed to predict the healing success of wounds following BKA. Ultrasonography is used in the evaluation of the carotid, kidneys, and peripheral arterial diseases; it is non-invasive and safe, resulting in no morbidity (11). Doppler ultrasonography is considered an ideal screening tool to assess the condition of arteries in inferior extremities and can be tolerated by most patients. Therefore, doppler ultrasonography might able to provide information to diagnose, determine treatment, and evaluate treatments of PAD cases. To date, no published studies have investigated the effectiveness of doppler ultrasonography to predict the healing following BKA. This study aims to prove the association between doppler ultrasonography findings with wound healing after below-knee amputation surgery in patients with peripheral arterial disease. We hypothesize that there is a strong association between doppler ultrasonography findings and primary wound healing following BKA.

\section{Mehods}

This study was a retrospective case-control study evaluating the effectiveness of doppler ultrasonography as a predictor of wound healing following BKA. We collected data from medical records of patients at Dr. Cipto Mangunkusumo General Hospital, Fatmawati General Hospital, and Tangerang District General Hospital, Indonesia in 2017, using consecutive sampling with a minimal sample size of 56 subjects. Ethical approval was given by the Ethics Committee of the Faculty of Medicine, Universitas Indonesia (approval number 1066/UN2.F1/ETIK/2017). The subjects in this study included all patients with peripheral arterial diseases who underwent BKA at Dr. Cipto Mangukusumo General Hospital, Fatmawati Hospital, and Tangerang District Hospital. Exclusion criteria were patients who died in the treatment period, patients with ascending infections, patients with congenital vascular abnormalities, and patients with hypoalbuminemia $(<3.5 \mathrm{~g} / \mathrm{dl})$. Age, gender, PAD stage diagnosis, and comorbidity data were collected as clinical baseline characteristics of each subject. The independent variables used in this study are distal artery spectral waveform as triphasic, biphasic, monophasic (triphasic waveform is considered normal) (12,13); peak systolic velocity as centimeter per second $(\mathrm{cm} / \mathrm{s}$ ) (normal values in popliteal artery and tibial arteries are $68 \pm 14$ and $55 \pm 10$, respectively); volume flow as milliliter/minute $(\mathrm{ml} / \mathrm{min}$ ) (normal values in the popliteal artery, anterior tibial artery, and posterior tibial artery are $107 \pm 22,24.32 \pm 15.71$, and $18.67 \pm 13.47$; respectively); and arterial diameter as centimeter $(\mathrm{cm})$ (normal values in popliteal artery and tibial arteries are $0.5 \pm 0.1$ and $0.3 \pm 0.4$, respectively) (13,14). Doppler ultrasonography assessment was conducted on the popliteal artery, anterior tibial artery, and posterior tibial artery. Then, we combined data of all arteries to be analyzed. A subject was categorized as having normal results in distal artery spectral waveform for all arteries if the results on popliteal, anterior tibial, and posterior tibial were one of the following respective combinations: Triphasic Triphasic Triphasic (TTT), Triphasic Triphasic Biphasic (TTB), Triphasic Biphasic Triphasic (TBT), Triphasic Triphasic Monophasic (TTM), Triphasic Monophasic Triphasic TMT, Triphasic Biphasic Biphasic (TBB), Triphasic Biphasic Monophasic (TBM), and Triphasic Monophasic Biphasic (TMB). Otherwise, the result would be classified as abnormal. Peak systolic velocity, artery diameter, and volume flow results for all arteries were also categorized as normal if the results showed one of the following respective result combinations: Normal Normal Normal (NNN), Normal Normal Abnormal (NNA), Normal Abnormal Normal (NAN), and Normal Abnormal Abnormal (NAA) for popliteal artery, anterior tibial artery, and posterior tibial artery assessment. Otherwise, the final result was considered abnormal. The dependent variable was wound healing following BKA. Wound healing with primary intention was defined as wound healing with no granulation tissue and 
minimal scar tissue observed (15). Statistical analysis was performed using IBM $^{\odot}$ SPSS $^{\circledR}$ version 20. Data processing was performed by conducting a descriptive analysis to determine the distribution of subjects. Bivariate analysis was performed afterward by looking at the relationship between distal artery indicators (spectral waveform, peak systolic velocity, arterial diameter, and volume flow) in the popliteal, anterior tibial arteries, and posterior tibial arteries and wound healing following BKA. Bivariate analysis, using the Chi-square test or Fisher's exact test, was also performed on a combination of all three arteries. Moreover, multivariate analysis was also performed to correlate all indicators in all arterial combinations with wound healing following BKA, using logistic regression analysis. p-values of less than 0.05 were considered statistically significant.

\section{Results}

Data of 58 subjects were consecutively taken from medical records of patients in 3 general hospitals. The average age of the subjects was $60.2 \pm 8.6$ years old; $53.4 \%$ of subjects were female and the other $46.6 \%$ were male. Based on the diagnosis, $65.6 \%$ of subjects were diagnosed with PAD and diabetes mellitus as comorbidity. Critical limb ischemia (CLI) was diagnosed in $31 \%$ of subjects and $3.4 \%$ of subjects were diagnosed with acute limb ischemia (ALI). On the wound healing status following BKA, most of the subjects (53.4\%) healed and the rest $(46.6 \%)$ failed to heal. The average artery diameter was $0.51 \pm 0.008 \mathrm{~cm}$ in the popliteal artery, $0.24 \pm 0.007 \mathrm{~cm}$ in the anterior tibial artery, and $0.23 \pm 0.008 \mathrm{~cm}$ in the posterior tibial artery. Based on the peak systolic velocity assessments, the average was $68.3 \pm 2.3 \mathrm{~cm} / \mathrm{s}$ in the popliteal artery, $37.9 \pm 2.4 \mathrm{~cm} / \mathrm{s}$ in the anterior tibial artery, and $34.2 \pm 2.15 \mathrm{~cm} / \mathrm{s}$ in the posterior tibial artery. The average volume flow in the popliteal artery, anterior tibial artery, and posterior tibial artery were $111.5 \pm 16.4$ $\mathrm{ml} /$ minute, $36.7 \pm 3.7 \mathrm{ml} /$ minute, and $22.65 \pm 2.73$ $\mathrm{ml} /$ minute respectively. Based on the bivariate analysis of the doppler ultrasonography assessment of the popliteal artery (Table 1), significant associations were observed in peak systolic velocity $(p=0.010)$, volume flow $(p=$ $0.001)$, and arterial diameter $(\mathrm{p}=0.020)$. However, distal artery spectral waveform assessment was not significantly associated with primary healing wound following BKA $(p=0.412)$. Only 2 subjects had abnormal findings on distal artery spectral waveform assessment of the popliteal artery, and both subjects failed to recover, compared to a total of 56 subjects with no abnormal findings. The insignificant $p$ value might be due to uneven distribution between the two groups. Based on the bivariate analysis on the anterior tibial artery, all indicators were significantly associated with healing after BKA surgeries. These included peak systolic velocity $(p=0.008)$, volume flow $(\mathrm{p}=0.004)$, arterial diameter $(p=0.004)$, and spectral waveform $(p=0.010)$. Moreover, the bivariate analysis on the posterior tibial artery also showed that the peak systolic velocity $(\mathrm{p}=0.008)$, volume flow $(p=0.0001)$, arterial diameter $(p=0.036)$, and spectral waveform $(p=0.0001)$ were significantly associated. The details on the bivariate analysis of the doppler ultrasonography assessment on each artery are provided in Table 1. We found $56.9 \%$ of subjects had normal distal artery spectral waveform of all arteries. The majority of subjects also had normal peak systolic velocity and artery diameter, which were $63.8 \%$ and $65.5 \%$ of subjects respectively. However, more than half $(55.2 \%)$ showed abnormal volume flow in doppler ultrasonography assessment. Based on the bivariate analysis on the combination of all arteries, all indicators of doppler ultrasonography assessment showed significant associations with wound healing after BKA surgeries (Table 2). Multivariate analysis was conducted in three stages. The details are reported in Table 3. Our sample size was found to be insufficient to assess the association between distal artery spectral waveform of all arteries to wound healing. This could be the cause of the extremely high adjusted OR of this variable in the first and second multivariate analysis (Table 3). Based on the multivariate 
Table 1. Association between doppler ultrasonography assessment results and healing status of below-knee amputation in each artery

\begin{tabular}{|c|c|c|c|c|c|c|c|c|}
\hline \multicolumn{9}{|c|}{ Healing Status } \\
\hline \multirow[t]{2}{*}{ Variable } & \multicolumn{2}{|c|}{ Failed } & \multicolumn{2}{|c|}{ Healed } & \multicolumn{2}{|c|}{ Total } & \multirow[t]{2}{*}{ p-value } & \multirow[t]{2}{*}{ OR (95\% CI) } \\
\hline & $\mathbf{n}$ & $\%$ & $\mathbf{n}$ & $\%$ & $\mathbf{n}$ & $\%$ & & \\
\hline \multicolumn{9}{|c|}{ Popliteal Artery } \\
\hline \multicolumn{9}{|c|}{ Volume Flow } \\
\hline Abnormal & 22 & 66.7 & 11 & 33.3 & 33 & 100.0 & $0.001^{*}$ & $8(2.4-27.1)$ \\
\hline Normal & 5 & 20 & 20 & 80 & 25 & 100.0 & & \\
\hline \multicolumn{9}{|c|}{ Peak Systolic Velocity } \\
\hline Abnormal & 15 & 71.4 & 6 & 28.6 & 21 & 100.0 & $0.010^{*}$ & $5.2(1.6-16.8)$ \\
\hline Normal & 12 & 32.4 & 25 & 67.6 & 37 & 100.0 & & \\
\hline \multicolumn{9}{|c|}{ Artery Diameter } \\
\hline Abnormal & 14 & 70 & 6 & 30 & 20 & 100.0 & $0.020 *$ & $4.5(1.4-14.4)$ \\
\hline Normal & 13 & 34.2 & 25 & 65.8 & 38 & 100.0 & & \\
\hline \multicolumn{9}{|c|}{ Distal Artery Spectral Waveform } \\
\hline Abnormal & 2 & 100 & 0 & 0 & 2 & 100.0 & $0.412^{\star \star}$ & - \\
\hline Normal & 25 & 46.6 & 31 & 55.4 & 56 & 100.0 & & \\
\hline \multicolumn{9}{|c|}{ Anterior Tibial Artery } \\
\hline \multicolumn{9}{|c|}{ Volume Flow } \\
\hline Abnormal & 18 & 69.2 & 8 & 30.8 & 26 & 100.0 & $0.004^{*}$ & $5.7(1.8-17.9)$ \\
\hline Normal & 9 & 28.1 & 23 & 71.9 & 32 & 100.0 & & \\
\hline \multicolumn{9}{|c|}{ Peak Systolic Velocity } \\
\hline Abnormal & 26 & 56.5 & 20 & 43.5 & 46 & 100.0 & $0.008^{*}$ & $14.3(1.7-120.2)$ \\
\hline Normal & 1 & 8.3 & 11 & 91.7 & 12 & 100.0 & & \\
\hline \multicolumn{9}{|c|}{ Artery Diameter } \\
\hline Abnormal & 26 & 57.8 & 19 & 42.2 & 45 & 100.0 & $0.004^{*}$ & $16.4(2.0-137.4)$ \\
\hline Normal & 1 & 7.7 & 12 & 92.3 & 13 & 100.0 & & \\
\hline \multicolumn{9}{|c|}{ Distal Artery Spectral Waveform } \\
\hline Abnormal & 16 & 69.6 & 7 & 30.4 & 23 & 100.0 & $0.010 *$ & $5.0(1.6-15.6)$ \\
\hline Normal & 11 & 31.4 & 24 & 68.6 & 35 & 100.0 & & \\
\hline \multicolumn{9}{|c|}{ Posterior Tibial Artery } \\
\hline \multicolumn{9}{|c|}{ Volume Flow } \\
\hline Abnormal & 25 & 80.6 & 6 & 19.4 & 31 & 100.0 & $0.0001^{*}$ & $52.1(9.6-283.3)$ \\
\hline Normal & 2 & 7.4 & 25 & 92.6 & 27 & 100.0 & & \\
\hline \multicolumn{9}{|c|}{ Peak Systolic Velocity } \\
\hline Abnormal & 26 & 56.5 & 20 & 43.5 & 46 & 100.0 & $0.008^{*}$ & $14.3(1.7-120.2)$ \\
\hline Normal & 1 & 8.3 & 11 & 91.7 & 12 & 100.0 & & \\
\hline \multicolumn{9}{|c|}{ Artery Diameter } \\
\hline Abnormal & 24 & 55.8 & 19 & 44.2 & 43 & 100.0 & $0.036 *$ & $5.1(1.2-20.5)$ \\
\hline Normal & 3 & 20 & 12 & 80 & 15 & 100.0 & & \\
\hline \multicolumn{9}{|c|}{ Distal Artery Spectral Waveform } \\
\hline Abnormal & 25 & 78.1 & 7 & 21.9 & 32 & 100.0 & $0.0001^{*}$ & $42.9(8.1-227.3)$ \\
\hline Normal & 2 & 7.7 & 24 & 92.3 & 26 & 100.0 & & \\
\hline
\end{tabular}

Normal

OR: Odd ratio; Cl: Confidence interval

${ }^{*}$ Chi-square test; ${ }^{* \star}$ Fisher's exact test

analysis, artery diameter, peak systolic velocity, association was found in the artery diameter and volume flow were significantly associated indicator assessment with the adjusted odd with the healing after BKA. The highest ratio of $6.507(\mathrm{p}=0.012)$. 
Table 2. Bivariate analysis of association between doppler ultrasonography assessment indicators and healing status after below-knee amputation in all arteries

\begin{tabular}{|c|c|c|c|c|c|c|c|c|}
\hline \multicolumn{9}{|c|}{ Healing Status } \\
\hline \multirow[t]{2}{*}{ Variable } & \multicolumn{2}{|c|}{ Failed } & \multicolumn{2}{|c|}{ Healed } & \multicolumn{2}{|c|}{ Total } & \multirow[t]{2}{*}{ p-value ${ }^{\dagger}$} & \multirow[t]{2}{*}{ OR $(95 \% \mathrm{CI})$} \\
\hline & $n$ & $\%$ & $n$ & $\%$ & $\mathrm{n}$ & $\%$ & & \\
\hline \multicolumn{9}{|c|}{ Volume Flow } \\
\hline Abnormal & 21 & 65.6 & 11 & 34.4 & 32 & 100.0 & 0.003 & $6.4(2.0-20.5)$ \\
\hline Normal & 6 & 23.1 & 20 & 76.9 & 26 & 100.0 & & \\
\hline \multicolumn{9}{|c|}{ Peak Systolic Velocity } \\
\hline Abnormal & 15 & 71.4 & 6 & 28.6 & 21 & 100.0 & 0.010 & $5.2(1.6-16.8)$ \\
\hline Normal & 12 & 32.4 & 25 & 67.6 & 37 & 100.0 & & \\
\hline \multicolumn{9}{|c|}{ Artery Diameter } \\
\hline Abnormal & 14 & 70 & 6 & 30 & 20 & 100.0 & 0.020 & $4.5(1.4-14.4)$ \\
\hline Normal & 13 & 34.2 & 25 & 65.8 & 38 & 100.0 & & \\
\hline \multicolumn{9}{|c|}{ Distal Artery Spectral Waveform } \\
\hline Abnormal & 19 & 76 & 6 & 24 & 25 & 100.0 & 0.0001 & $9.9(2.9-33.4)$ \\
\hline Normal & 8 & 24.2 & 25 & 75.8 & 33 & 100.0 & & \\
\hline
\end{tabular}

OR: Odd ratio; Cl: Confidence interval

${ }^{\dagger}$ Chi-square test

Table 3. Multivariate analysis of association between doppler ultrasonography assessment and healing status after below-knee amputation in all arteries

\begin{tabular}{|c|c|c|c|c|}
\hline \multirow[t]{2}{*}{ Variable } & \multirow[t]{2}{*}{ Adjusted OR } & \multicolumn{2}{|c|}{ 95\% $\mathrm{Cl}$ for adjusted OR } & \multirow[t]{2}{*}{ p-value } \\
\hline & & Lower & Upper & \\
\hline \multicolumn{5}{|l|}{ Multivariate analysis I } \\
\hline Spectral Waveform & 193.388 & 7.603 & 4918.826 & 0.001 \\
\hline Artery Diameter & 83.919 & 4.284 & 1643.865 & 0.004 \\
\hline Peak Systolic Velocity & 17.044 & 1.462 & 198.762 & 0.024 \\
\hline Volume Flow & 10.567 & 1.313 & 85.026 & 0.027 \\
\hline Constant & 0.000 & & & 0.001 \\
\hline \multicolumn{5}{|l|}{ Multivariate analysis II } \\
\hline Spectral Waveform & 98.245 & 6.389 & 1510.646 & 0.001 \\
\hline Artery Diameter & 86.504 & 4.967 & 1506.668 & 0.002 \\
\hline Peak Systolic Velocity & 22.965 & 2.395 & 220.211 & 0.007 \\
\hline Constant & 0.001 & & & 0.001 \\
\hline \multicolumn{5}{|l|}{ Multivariate analysis III } \\
\hline Artery Diameter & 6.507 & 1.510 & 28.033 & 0.012 \\
\hline Peak Systolic Velocity & 5.584 & 1.291 & 24.157 & 0.021 \\
\hline Volume Flow & 4.760 & 1.200 & 18.876 & 0.026 \\
\hline Constant & 0.063 & & & 0.001 \\
\hline
\end{tabular}

OR: Odd ratio; Cl: Confidence interval

ILogistic regression analysis

\section{Discussion}

All indicators of doppler ultrasonography assessment were significantly associated with the healing after BKA, based on the bivariate analysis of doppler ultrasonography assessment on each artery (popliteal, anterior tibial, and posterior tibial arteries). However, the association between distal artery spectral waveform of the popliteal artery and wound healing following BKA was not significant. Based on bivariate analysis, all doppler ultrasonography assessments on all arteries showed significant associations with primary wound healing. Moreover, there were significant associations of peak systolic velocity (adjusted 
$\mathrm{OR}=5.584,95 \% \mathrm{CI}=1.291-24.157, \mathrm{p}=0.021)$, volume flow (adjusted OR=4.760, 95\% $\mathrm{CI}=1.200-18.876, \mathrm{p}=0.026)$, and arterial diameter (adjusted $\mathrm{OR}=6.507,95 \% \mathrm{CI}=1.510$ - 28.033, $\mathrm{p}=0.012$ ) with wound healing status, based on the multivariate analysis of all arteries. The main objective of amputation in peripheral arterial disease is to provide rehabilitation $(16,17)$. This should be achieved by preserving the knee joint while ensuring primary wound healing after the surgery. Hence, a non-invasive yet effective modality is needed as an important adjunct to clinical decision-making in achieving these two objectives. Doppler ultrasonography examination can provide information on the severity of stenosis by looking at the arterial diameter, peak systolic velocity, volume flow, and spectral waveforms of blood flow in the arteries, which are important in assessing peripheral hemodynamic blood flow (11). Ultrasonography examination is mainly indicated in 50-69 years old patients with diabetes and smoking activities, aged $\geq 70$ years with symptoms of leg pain or function reduction, a vascular examination of abnormal limbs, and patients with cardiovascular disease (18). Janssen et al. described that occlusion in the aortoiliac trajectory or deep femoral artery detected on ultrasonography imaging indicated a higher level of amputation (19). Moreover, they also reported discrepancies between results of physical examination and ultrasonography of $64 \%$ and $25 \%$ of femoral and popliteal pulsations respectively in determining the best amputation level (19). Hence, this study supports the findings of our study. The average peak systolic velocity in this study on the popliteal artery was higher than the result of a previous study by Liang et al., where the average peak systolic velocity on the popliteal artery was $54.1 \pm 10.5$ (20). Meanwhile, the average of peak systolic velocity on both tibial arteries were slightly lower than previous studies. A study by Crawford et al. reported average peak systolic velocity of $43.7 .1 \pm 31.4$ in anterior tibial artery and $43.4 \pm 42.3$ in posterior tibial artery (21). Ultrasonography, with Pulse wave (PW) mode, can evaluate stenosis by measuring the peak systolic velocity of the artery. Minimally, a 50-75\% arterial stenosis usually results in spectral waveform change from triphasic to monophasic with a decrement of peak systolic velocity value on the distal artery $(13,22)$. Assessing the diameter of arteries is of notable importance. This diameter changes in relation to the remodeling process. Based on a previous study by Vink et al., remodeling that leads to the shrinkage of the arterial wall is a main determinant of arterial stenosis (23). Therefore, it is supported by previous studies that artery diameter can potentially be a parameter of perfusion status in peripheral arterial disease. Moreover, the mean values of volume flow in three arteries in this study was also higher than the previous studies, which reported flow volume with an average of $107 \pm 22 \mathrm{ml} / \mathrm{min}$ in the popliteal artery, $29.76 \pm 26.00 \mathrm{ml} / \mathrm{min}$ in the anterior tibial artery, and $22.45 \pm 24.06 \mathrm{ml} / \mathrm{min}$ in posterior tibial artery (24). Arterial volume flow was considered associated with perfusion abnormality status in peripheral arterial disease on lower extremities. Distal artery spectral waveform assessment on the popliteal artery was the only factor with insignificant association with wound after BKA $(p=0.412)$. This was caused by uneven distribution between groups, where there were only 2 patients with abnormal waveforms, and all of them recovered after BKA. Moreover, the association between distal artery spectral waveform and wound healing after BKA in multivariate analysis could not be analysed due to an insufficient number of subjects. We recognize that our study has limitations. Some confounding variables such as cardiac function, coronary arterial disease comorbidity, surgeon ability, surgery equipment, and other inoperative factors need to be analysed to exclude any bias in this study. Further research with prospective cohort design may also lead to better results to analyse the effectiveness of ultrasonography in predicting the healing of BKA. Moreover, the small number of subjects in this study and the uneven distribution of subjects' characteristics also limited this study, especially in determining the association 
between distal artery spectral waveform indicator and wound healing following BKA.

\section{Conclusions}

In conclusion, indicators of doppler ultrasonography assessment (peak systolic velocity, volume flow, and arterial diameter) were shown to be significantly associated with wound healing after BKA $(p<0.05)$. Therefore, Doppler ultrasonography can be considered to be a pre-amputation testing modality to predict wound healing after BKA surgery.

\section{Acknowledgements}

The authors would like to thank dr. Kevin Varian and dr. Anggindita Diah for assisting the publication of this study.

\section{Conflicts of Interest and Source of Funding}

The authors declared no conflict of interest and no funding source in this study.

\section{References}

1. Duff S, Mafilios MS, Bhounsule P, Hasegawa JT. The burden of critical limb ischemia: A review of recent literature. Vasc Health Risk Manag. 2019;15:187-208.

2. Uccioli L, Meloni M, Izzo V, Giurato L, Merolla S, Gandini R. Critical limb ischemia: current challenges and future prospects. Vasc Health Risk Manag. 2018;14-63.

3. Labarthe DR. Epidemiology and Prevention of Cardiovascular Diseases: A Global Challege. Sudbury: Jones and Bartlett Publishers; 2011. p. 115

4. Nehler MR, Duval S, Diao L, Annex BH, Hiatt WR, Rogers K, et al. Epidemiology of peripheral arterial disease and critical limb ischemia in an insured national population. J Vasc Surg [Internet]. 2014:60(3):686-695.e2.

5. Moazzami K, Moazzami B, Roohi A, Nedjat S, Dolmatova E. Local intramuscular transplantation of autologous mononuclear cells for critical lower limb ischaemia. Cochrane Database Syst Rev. 2014; 2014(12).

6. Kim J, Chun D II, Kim S, Yang HJ, Kim JH, Cho JH, et al. Trends in lower limb amputation in patients with diabetic foot based on vascular intervention of peripheral arterial disease in Korea: A population-based nationwide study. J Korean Med Sci. 2019; 34(26): $1-8$.

7. Jarvis, HL, Bennett, AN, Twiste, M, Phillip, RD, Etherington, J,
Baker, R. Temporal Spatial and Metabolic Measures of Walking in Highly Functional Individuals With Lower Limb Amputations. Arch Phys Med Rehabil. 2017;98(7):1389-99.

8. AbuRahma AF, Bergan JJ. Noninvasive Vascular Diagnosis: A Pratical Guide to Therapy. London: Springer-Verlag; 2007. p. 356.

9. Berli MC, Wanivenhaus F, Kabelitz M, Götschi T, Böni T, Rancic Z, et al. Predictors for reoperation after lower limb amputation in patients with peripheral arterial disease. Vasa - Eur J Vasc Med. 2019;48(5):419-24.

10. Vemulapalli S, Greiner MA, Jones WS, Patel MR, Hernandez AF, Curtis LH. Peripheral arterial testing before lower extremity amputation among Medicare beneficiaries, 2000 to 2010. Circ Cardiovasc Qual Outcomes. 2014;7(1):142-150.

11. Ter Haar G. Ultrasonic imaging: safety considerations. Interface Focus. 2011;1(4):686-697.

12. Gerhard-Herman M, Gardin JM, Jaff M, Mohler E, Roman M, Naqvi TZ. Guidelines for Noninvasive Vascular Laboratory Testing: A Report from the American Society of Echocardiography and the Society of Vascular Medicine and Biology. J Am Soc Echocardiogr. 2006;19(8):955-72.

13. Stone PA, Hass SM. Vascular laboratory: Arterial dupplex scanning. In: Cronenwett JL, Johnston KW. Rutherford's vascular surgery, 8th ed. Philadelphia: Elsevier; 2014. p. 230-46.

14. Jager KA, Ricketts HJ, Strandness DE Jr: Duplex scanning for the evaluation of lower limb arterial disease. In Bernstein EF, editor: Noninvasive diagnostic techniques in vascular disease, St. Louis, 1985, Mosby, pp 619-631.

15. Singh S, Young A, McNaught CE. The physiology of wound healing. Surg (United Kingdom) [Internet]. 2017;35(9):473-7.

16. Torbjörnsson E, Ottosson C, Blomgren L, Boström L, Fagerdahl A-M. The patient's experience of amputation due to peripheral arterial disease. J Vasc Nurs [Internet]. 2017;35(2):57-63.

17. Swaminathan A, Vemulapalli S, Patel MR, Jones WS. Lower extremity amputation in peripheral artery disease: Improving patient outcomes. Vasc Health Risk Manag.2014:10:417-24.

18. McDermott MMG. Lower Extremity Manifestations of Peripheral Artery Disease: The Pathophysiologic and Functional Implications of Leg Ischemia. Circ Res. 2015;116(9):1540-50.

19. Janssen ERI, van Silfhout L. Duplex Ultrasound May Predict the Best Level of Lower Limb Amputation in Patients with Chronic Limb-Threatening Ischemia: A Retrospective Observational Cohort Study. Ann Vasc Surg. Epub 2020 Mar 20.

20. Liang HL. Doppler flow measurement of lower extremity arteries adjusted by pulsatility index. Am J Roentgenol. 2020;214(1): $10-7$.

21. Crawford JD, Robbins NG, Harry LA, Wilson DG, McLafferty RB, Mitchell EL, et al. Characterization of tibial velocities by duplex ultrasound in severe peripheral arterial disease and controls Presented as an oral presentation at the 2015 Vascular Annual Meeting of the Society for Vascular Surgery, Chicago, III, June 1720, 2015. J Vasc Surg [Internet]. 2016;63(3):646-51.

22. Donnelly $R$, Hinwood D, London NJM. Non-invasive methods of arterial and venous assessment Principles of vascular ultrasonography. Clin Rev ABC. 2000;320:698-701.

23. Vink A, Schoneveld AH, Borst C, Pasterkamp G. The contribution of plaque and arterial remodeling to de novo atherosclerotic luminal narrowing in the femoral artery. J Vasc Surg. 2002;36(6):1194-7.

24. Sekiya N, Ichioka S. Efficacy of Ultrasonography at the Ankle Level for Estimation of Pedal Microcirculation. Ann Vasc Dis. 2015;8(3): 198-202. 